\title{
A cross-sectional study to estimate the frequency of anti-bovine viral diarrhea virus-1 antibodies in domestic pigs of Mossoró region in the state of Rio Grande do Norte, Brazil
}

\author{
Estudo transversal para estimar a frequência de anticorpos anti-vírus da diarreia viral bovina-1 \\ em suínos domésticos da região de Mossoró, no estado do Rio Grande do Norte, Brasil
}

\author{
Igor Renan Honorato Gatto ${ }^{I}$ Andreia Gonçalves Arruda ${ }^{I I}$ Henrique Meiroz de Souza Almeida \\ Glaucenyra Cecília Pinheiro da Silva ${ }^{I}$ Alexandro Iris Leite ${ }^{I I I}$ Samir Issa Samara ${ }^{I}$ \\ Iveraldo dos Santos Dutra ${ }^{\text {IV }}$ Renato Akio Ogata $^{\mathrm{V}}$ Luis Guilherme de Oliveira ${ }^{\mathrm{VI}}$
}

\section{ABSTRACT}

This study investigated the occurrence of antibodies for BVDV-1 in swine herds located in the region of Mossoró city of the state of Rio Grande do Norte, Brazil. A sample size of 412 animals was estimated assuming unknown prevalence (set at $50 \%$ ). Virus neutralization assay was used to the detect the presence of antibodies for $B V D V-1$ and the results found were analysed using multivariable logistic regression model. The obtained prevalence was $4 \%$ at animal level and $45 \%$ at the animal and herd level. The titers were highly variable between animals and within farms. The multivariable logistic regression analysis showed an association between being housed outside and exposure to BVDV-1 (OR=0.24, 95\% CI:0.06, 0.96, P=0.04). Highly correlated data and low prevalence of antibodies at the animal level resulted in insufficient power to detect significant differences with other selected risk factors. In conclusion, the prevalence is within the range reported for other countries.

Key words: swine, pestiviruses, virusneutralization, $B V D V, C S F V$.

RESUMO

Este estudo investigou a ocorrência de anticorpos contra o BVDV-1 em rebanhos suínos localizados na região da cidade de Mossoró do Estado do Rio Grande do Norte, Brasil. Um tamanho de amostra de 412 animais foi estimado assumindo uma prevalencia desconhecida (fixada em 50\%). O teste de virusneutralização foi utilizado para detectar a presença de anticorpos ao BVDV-1 e os resultados obtidos foram analisados usando o modelo de regressão logística multivariada. A prevalência obtida foi de $4 \%$ em nivel animal e de $45 \%$ dos rebanhos. Os titulos foram muito variáveis entre os animais e dentro de fazendas. A análise de regressão logística multivariada apontou associação entre animais criados soltos e a exposição ao BVDV-1 $(O R=0,24$; 95\% IC: 0,06; 0,96; $P=0.04)$. A alta correlação entre os dados junto com a baixa prevalência de anticorpos a nivel animal pode ter sido insuficiente para que as diferenças reais fossem detectadas. Em conclusão, a prevalência está dentro do intervalo referido em outros países.

Palavras-chave: suínos, pestivírus, virusneutralização, BVDV, CSFV.

\section{INTRODUCTION}

The Pestivirus genus includes Classic Swine Fever Virus (CSFV), Bovine Viral Diarrhea Virus (BVDV-1 and BVDV-2), Border Disease Virus (BDV) (BECHER et al., 2003), and other putative species such as Hobi-like virus (SCHIRRMEIER et al., 2004) and Bungowannah (KIRKLAND et al., 2007). These virus are enveloped single-stranded RNA viruses that cause important diseases in several food animals species (KIRKLAND et al., 2012). In 1973, a field strain of BVDV was isolated for the first time from a naturally infected sow and her piglet, evidencing that swine could be a host

\footnotetext{
'Departamento de Medicina Veterinária Preventiva e Reprodução Animal, Faculdade de Ciências Agrárias e Veterinárias (FCAV), Universidade Estadual Paulista (UNESP), Jaboticabal, SP, Brasil.

IIDepartamento de Medicina Populacional, Universidade de Guelph, Guelph, ON, Canadá.

III Universidade Federal Rural do Semi-Árido (UFERSA), Rio Grande do Norte, RN, Brasil.

${ }^{\text {IV }}$ Departamento de Apoio, Produção e Saúde Animal, Faculdade de Medicina Veterinária (FMVA), Universidade Estadual Paulista (UNESP), Araçatuba, SP, Brasil.

VInstituto Biológico (IB/APTA/SAA-SP), São Paulo, SP, Brasil.

VIDepartamento de Clínica e Cirurgia Veterinária, Faculdade de Ciências Agrárias e Veterinárias (FCAV), Universidade Estadual Paulista (UNESP), 14884-900, Jaboticabal, SP, Brasil. E-mail: luis.guilherme@fcav.unesp.br. Corresponding author. 
for ruminant Pestivirus (FERNELIUS et al., 1973). Although BVDV infection does not commonly produce clinical signs in swine, a "mild Classical Swine Fever" syndrome has been reported (LIESS \& MOENNIG, 1990; TAO et al., 2013), as well as reproductive problems in breeding animals such as abortions, weak born piglets, and digestive problems (KIRKLAND et al., 2012).

The prevalence of BVDV infections in swine varies according to region, ranging anywhere from 0 to 43.5\% (LOEFFEN et al., 2009; O'SULLIVAN et al., 2011; DENG et al., 2012). In Ireland, the prevalence was reported to be very low, $0.14 \%$ (GRAHAM et al., 2001 ), whereas in The Netherlands, $2.5 \%$ of sows and $0.42 \%$ of finishing pigs were seropositive (LOEFFEN et al., 2009). Furthermore, in China, between $20 \%$ to $34 \%$ of swine from 11 different provinces during 2007 2010 were found to have been exposed to BVDV-1 (DENG et al., 2012).

Epidemiological studies show that cattle are the main hosts for BVDV and an infection source for swine and other wild ruminants, either through direct contact (LIESS \& MOENNIG, 1990) or through the use of contaminated bovine milk and milk derivatives used as components in swine feed (TERPSTRA \& WENSVOORT, 1988).

There is a lack of peer-reviewed publications on BVDV infection in swine in Brazil; therefore, the primary objective of the present study was to estimate the prevalence of BVDV-1 antibodies in swine herds located in the Rio Grande do Norte state of Brazil, and determine correlation between seropositivity and selected risk factors.

\section{MATERIALS AND METHODS}

The study was conducted in the region of Mossoró municipality, in the state of Rio Grande do Norte, which has a total of 6.046 pigs, the greatest amount in the state (IBGE, 2012). A sample size of 385 animals was estimated assuming unknown prevalence (set at 50\%), level of confidence of $95 \%$ and margin of error of 5\%, 412 blood samples were collected between January and June of 2013 of animals from one slaughterhouse facility, also located in Mossoró. Eligibility criteria included that animals had to be slaughtered in the selected slaughterhouse (convenience sample) and farm owners were required to sign a consent form agreeing to participate in the study. Animal data was collected from producers at the time of sample collection.

Blood samples were centrifuged, and serum samples were stored at $-20^{\circ} \mathrm{C}$ and the virus neutralization assays was undertaken. All samples were processed in duplicate, following the World Organization for Animal Health (OIE) guidelines (OIE, 2015), using Madin Darby Bovine Kidney (MDBK) cell culture and BVDV strain Singer-1a using $100 \mathrm{TCID}_{50}$ concentration.

Samples were not tested for Border disease, because this disease is exotic in Brazil; therefore, it was not possible to perform this test. Regarding the Classical swine fever diagnosis, it must be performed in official laboratories and we did not have authorization from Ministry of Agriculture, Livestock. The BVDV-2 was not performed, because of the insufficient volume of samples.

Analyses were conducted at the animal level, and the outcome was binary (positive or negative) based on an antibody titer of $>/=10$. The final titer was obtained from the geometric mean of titers and the final data were transformed in $\log$ base format .

The 20 largest supliers were visited by the study investigators to gather information about the herd demographics for the risk factor analyses. The questionnaire used is available upon request to the authors. Descriptive analysis was conducted using SAS 9.3. Two types of statistical models were constructed using STATA-IC 10 in order to investigate animal age and farm practices as risk factors for BVDV infection. Independent variables considered during analyses included animal age (market age/“young" or culling animals/“"old"), herd size (continuous variable), housing type (free range or confined), use of human food scraps to feed pigs, use of treated water, presence of bovine species in the farm, presence of sheep or goats in the farm, and the occurrence of abortion in the herd.

First, a multivariable logistic regression model was constructed, which did not account for the clustering of animals within farms ("unadjusted model"). Univariable analyses were conducted and all variables with $P<0.20$ were offered to the full model. Subsequently, a backwards stepwise approach was taken, with statistical significance declared when $P<0.05$. Confounders were defined as variables that modified the coefficients of one or more of the other predictors' coefficients by $20 \%$ or more, and were kept in the model regardless of their statistical significance. One-way interactions with variables retained in the final model were tested and kept if $P<0.05$.

For the second model, a multivariable model using a generalized estimating equation (GEE) approach was attempted in order to account for the clustering of animals within farms ("adjusted model"). 
The correlation structure used was independent. The same steps described above were used, but because none of the predictors had $P<0.20$ in the univariable analysis, none moved forward to a multivariable model.

\section{RESULTS AND DISCUSSION}

Prevalence of antibodies for BVDV-1 at the animal and farm level were $4.13 \%$ (17/412, 95\% CI: $2.21 \%-6.05 \%)$, and $45.0 \%$ (9/20, 95\% CI: $23.20 \%-66.80 \%$ ), respectively. Mean within-herd prevalence was estimated to be $4.23 \%$ (range: $2.0 \%$ to $29.0 \%$ ). The titers were highly variable between animals and, in a few cases, within farms (Table 1).

The observed prevalence for BVDV-1 antibodies at the animal level is within the prevalence reported in the literature (GRAHAM et al., 2001; LOEFFEN et al., 2009; DENG et al., 2012). At the herd level, the observed prevalence is higher than previously reported. According to O'Sullivan (2011), there was a $0 \%$ prevalence in Ontario (Canada). KIRKLAND et al. (2012) and LIESS \& MOENNING (1990) reported a prevalence between
$2 \%$ to $43 \%$ in US herds; and LOEFFEN et al. (2009) reported that $11 \%$ of herds in The Netherlands were seropositive. According to SCHROEDER et al. (2012), three out of the seven most used ELISA commercial kit for CSF serological diagnosis were poorly able to differentiate anti-BVDV antibodies from anti-CSFV antibodies in swine serum. Thus, the presence of anti BVDV antibodies in pig herds could lead to false-positive CSF results, hindering CSF surveillance and eradication programs based on serological diagnosis (DE SMIT et al., 1999).

Members of the Pesitivirus genus have great antigenic similarity and there are reports of cross-reaction in the virus-neutralization test (SIMMONDS et al., 2011). However, scientific papers have shown that antigenic differences were still detected among genotypes and subgenotypes within this genus by the same virus-neutralizatiton assay (BECHER et al., 2003; RIDPATH et al., 2010; BEHERA et al., 2011; PECORA et al., 2014). In addition, among the bovine pestivirus groups, the Hobi-like virus was found to be the most antigenically different from BVDV-1 and 2 (BAUERMANN et al.,

Table 1 - Within-herd prevalence of virus neutralizing antibodies for bovine viral diarrhea virus-1 in animals from 20 different farms.

\begin{tabular}{lcl}
\hline Farm & Within-herd prevalence $\%(\mathrm{P} / \mathrm{N})^{\mathrm{a}}$ & Distribution of VNA titers ${ }^{\mathrm{b}}$ \\
\hline $\mathrm{A}$ & $0.0(0 / 35)$ & - \\
$\mathrm{B}$ & $1.8(1 / 55)$ & $10(1)$ \\
$\mathrm{C}$ & $0.0(0 / 12)$ & - \\
$\mathrm{D}$ & $11.8(4 / 34)$ & $640(1), 320(1), 10(2)$ \\
$\mathrm{E}$ & $7.7(1 / 13)$ & - \\
$\mathrm{F}$ & $0.0(0 / 7)$ & - \\
$\mathrm{G}$ & $0.0(0 / 33)$ & - \\
$\mathrm{H}$ & $0.0(0 / 30)$ & $640(1), 160(1)$ \\
$\mathrm{I}$ & $28.6(2 / 7)$ & $10(1)$ \\
$\mathrm{J}$ & $9.1(1 / 11)$ & - \\
$\mathrm{K}$ & $0.0(0 / 4)$ & - \\
$\mathrm{L}$ & $0.0(0 / 5)$ & - \\
M & $7.7(1 / 13)$ & $10(1)$ \\
N & $0.0(0 / 8)$ & $160(1), 80(2), 40(2)$ \\
O & $3.2(1 / 31)$ & - \\
$\mathrm{P}$ & $9.4(5 / 53)$ & - \\
$\mathrm{Q}$ & $0.0(0 / 21)$ & - \\
$\mathrm{R}$ & $0.0(0 / 11)$ & - \\
S & $0.0(0 / 15)$ & $20(1)$ \\
T & $7.1(1 / 14)$ & \\
Total & $4.13(17 / 412)$ & \\
\hline
\end{tabular}

${ }^{\mathrm{a}}$ The fraction in brackets correspond to total of animals tested positive (P) in the virus neutralizing antibody (VNA) assay divided by total of animals tested $(\mathrm{N})$ in the farm.

${ }^{b}$ Number in brackets correspond to the number of animals within the herd with that specific antibody titer. 
2012). Considering all pestivirus genus, Pronghorn, Bungowannah and Atypical Putative Porcine Virus (App V), are more divergent to those virus than Hobi-like (BAUERMANN et al., 2012; NEILL et al., 2014; HAUSE et al., 2015; KIRKLAND et al., 2015). However, we cannot rule out that the neutralizing antibodies detected were induced by other pestivirus infection than BVDV-1.

Multivariable logistic regression analysis showed an association between being housed outside and exposure to BVDV-1 (OR=0.24, 95\% CI:0.06, $0.96, P=0.04)$. Herd size was found to be a confounder in this association and therefore was controlled in the model $(\mathrm{OR}=1.005, \mathrm{CI}$ : $0.99-1.01, P=0.05)$. This association was no longer significant when accounting for the lack of independence of animals among farms using the GEE approach (Table 2).

Findings of multivariable logistic regression analysis were different of the expected since previous reports found that having other animal species such as bovine, goats and sheep in the same farm is a risk factor for infection by BVDV-1 (LOEFFEN et al., 2009). Occurrence of abortions, and other reproductive problems has also been previously reported to be associated with BVDV infection in pregnant cattle (BECHER et al., 2003). Moreover, infected ruminants are considered the main infection source of BVDV for swines (DENG et al., 2012).

Regarding the risk factor analysis, we were not able to associate any other variable with the disease occurrence. Considering the highly correlated data and low prevalence of antibodies at the animal level, there may have been insufficient power to detect true differences. The sample size was originally calculated with the objective of estimating prevalence; therefore, it did not necessarily meet the requirements for risk factor analysis.

In conclusion, anti-BVDV antibodies were detected in swine serum from Mossoró what could hinder the on going CSFV surveillance and eradication programs in the state of Rio Grande do Norte.

Table 2 - Distribution of variable categories by status for seropositivity to bovine viral diarrhea virus-1, with adjusted and non-adjusted Pvalues.

\begin{tabular}{|c|c|c|c|c|}
\hline Variable and levels & Positive N (\%) & Negative N $(\%)^{\mathrm{a}}$ & Unadjusted P-value $^{\mathrm{b}}$ & Adjusted P-value $^{c}$ \\
\hline Young & $11(64.7 \%)$ & $215(54.5 \%)$ & 0.41 & 0.54 \\
\hline Old & $6(35.3 \%)$ & $180(45.6 \%)$ & & \\
\hline Access outside & $8(47.1 \%)$ & $\begin{array}{l}\text { Housing type--- } \\
251(63.5 \%)\end{array}$ & 0.17 & 0.31 \\
\hline No access & $9(52.9 \%)$ & $144(36.5 \%)$ & & \\
\hline Present & $3(17.6 \%)$ & $\begin{array}{r}\text {-Bovine-------- } \\
121(27.8 \%)\end{array}$ & 0.26 & 0.28 \\
\hline Absent & $14(82.3 \%)$ & $274(72.2 \%)$ & & \\
\hline Present & $9(52.9 \%)$ & $\begin{array}{c}\text { Sheep/ Goat--- } \\
190(30.6 \%)\end{array}$ & 0.70 & 0.78 \\
\hline Absent & $8(47.1 \%)$ & $205(69.4 \%)$ & & \\
\hline Yes & $6(35.3 \%)$ & $\begin{array}{c}\text { e of treated water-- } \\
110(27.8 \%)\end{array}$ & 0.51 & 0.58 \\
\hline No & $11(64.7 \%)$ & $285(72.2 \%)$ & & \\
\hline & & --Abortion------- & & \\
\hline Yes & $10(58.8 \%)$ & $167(42.3 \%)$ & 0.18 & 0.34 \\
\hline No & $7(41.2 \%)$ & $228(57.7 \%)$ & & \\
\hline Yes & $12(70.6 \%)$ & $\begin{array}{c}\text { od scrapes---- } \\
326(39.7 \%)\end{array}$ & 0.22 & 0.24 \\
\hline No & $5(29.4 \%)$ & $69(60.3 \%)$ & & \\
\hline
\end{tabular}

${ }^{\mathrm{a}}$ Number of animals tested positive or negative in the virus neutralizing antibody assay for BVDV-1, frequency in brackets correspond to the percentage in each category among positive/ negative.

${ }^{\mathrm{b}} \mathrm{P}$-value from univariable logistic regression models, not adjusted for clustering of animals within farms.

${ }^{\mathrm{c}} \mathrm{P}$-value from generalizing estimation equation models, adjusting for clustering of animals within farms . 


\section{CONFLICT OF INTEREST}

The authors declare that they have no competing interests.

\section{BIOETHICS AND COMMITTEE APPROVAL}

The study was approved by Ethics Committee on Animal Use (CEUA) of Universidade Federal Rura do Semi-Árido, registered on N. $02 / 2013$ and process N. 23091.003915/2012-42 CEUA/UFERSA.

\section{ACKNOWLEDGEMENTS}

The authors would like to acknowledge the farm owners and the laboratory staff of Departamento de Medicina Veterinária Preventiva e Reprodução Animal of Universidade Estadual Paulista "Júlio de Mesquita Filho" Câmpus de Jaboticabal, and Instituto Biológico do Estado de São Paulo. The financial support provided by grant 2014/13590-3, Fundação de Amparo à Pesquisa do Estado de São Paulo (FAPESP) and for the scholarship by grant 132665/2014-0, Conselho Nacional de Desenvolvimento Científico e Tecnológico $(\mathrm{CNPq})$.

\section{REFERENCES}

BAUERMANN, F.V. et al. Antigenic relationships between Bovine viral diarrhea virus 1 and 2 and $\mathrm{HoBi}$ virus: possible impacts on diagnosis and control. Journal of Veterinary Diagnostic Investigation, v.24, n.2, p.253-261, mar. 2012. Available from: $<$ http://www.ncbi.nlm.nih.gov/pubmed/22379042>. Accessed: Nov. 09, 2015. doi: 10.1177/1040638711435144.

BECHER, P. et al. Genetic and antigenic characterization of novel pestivirus genotypes: implications for classification. Virology, v.311, n.1, p.96-104, 2003. Available from: <http://www.ncbi. nlm.nih.gov/pubmed/12832207>. Accessed: Jun. 17, 2015. doi: 10.1016/S0042-6822(03)00192-2.

BEHERA, S.P. et al. Genetic and antigenic characterization of bovine viral diarrhea virus type 2 isolated from cattle in India. Comparative Immunology, Microbiology and Infectious Diseases, v.34, n.2, p.189-196, 2011. Available from: <http:// www.ncbi.nlm.nih.gov/pubmed/21112633>. Accessed: Nov. 09, 2015. doi: 10.1016/j.cimid.2010.11.002.

DE SMIT, A.J. et al. Laboratory decision making during the classical swine fever epidemic of 1997-1998 in the Netherlands. Preventive Veterinary Medicine, v.42, p.185-199, 1999. Available from: $<$ http://www.ncbi.nlm.nih.gov/pubmed/10619155>. Accessed: Oct. 26, 2015. PMID: 10619155.

DENG, Y. et al. High prevalence of bovine viral diarrhea virus 1 in Chinese swine herds. Veterinary Microbiology, v.159, n.3-4, p.490-493, 2012 Available from: <http:/www.ncbi.nlm.nih.gov/pubmed/22613254>. Accessed: Jun. 17, 2015. doi: 10.1016/j.vetmic.2012.04.023.

FERNELIUS, A.L. et al. Bovine viral diarrhoea vírus in swine: characteristics of vírus recovered from naturally and experimentally infected swine. Canadian Journal of Medicine, v.37, n.1, p.13-20, 1973. Available from: <http://www.ncbi. nlm.nih.gov/pmc/articles/PMC1319716/>. Accessed: Jun. 17 2015. PMC1319716.
GRAHAM, D.A. et al. Pestivirus in sheep and pigs in Northern Ireland. Veterinary Record, v.148, p.69-72, 2001. Available from: $<$ http://veterinaryrecord.bmj.com/content/148/3/69>. Accessed: Jun. 17, 2015. doi: 10.1136/vr.148.3.69.

HAUSE, B.M. et al. Discovery of a novel putative atypical porcine pestivirus in pigs in the USA. Journal of General Virology, v.96, n.10, p.2994-2998, 2015. Available from: <http://www.ncbi. nlm.nih.gov/pubmed/26219947>. Accessed: Jan. 13, 2016. doi: 10.1099/jgv.0.000251

IBGE (BRAZILIAN INSTITUTE OF GEOGRAPHY AND STATISTICS). Produção da Pecuária Municipal. Rio de Janeiro, 2012. v.40, p.1-71. Available from: $<$ http//ftp.ibge.gov. br/Producao_Pecuaria/Producao_da_Pecuaria_Municipal/2012/ ppm2012.pdf>. Accessed: Jul. 19, 2014.

KIRKLAND, P.D. et al. Identification of a novel virus in pigs Bungowannah virus: a possible new species of pestivirus. Vírus Research, v.129, n.1, p.26-34, 2007. Available from: <http://www. ncbi.nlm.nih.gov/pubmed/17561301>. Accessed: Oct. 26, 2015.

KIRKLAND, P.D. et al. Pestiviruses. In: ZIMMERMAN, J.J. et al. (Eds.). Diseases of swine. 10.ed. UK: John Wiley \& Sons, 2012. p.538-553. ISBN: 978-0-8138-2267-9.

KIRKLAND, P.D. et al. Genetic and antigenic characterization of Bungowannah virus, a novel pestivirus. Veterinary Microbiology, v.178, n.3-4, p.252-259, 2015. Available from: <http://www. sciencedirect.com/science/article/pii/S0378113515002102>. Accessed: Jan. 13, 2016. doi:10.1016/j.vetmic.2015.05.014.

LIESS, B.; MOENNIG, V. Ruminant pestivirus infection in pigs. Revue Scientifique et Technique, v.9, n.1, p.151-161, 1990. Available from: $<$ http://www.ncbi.nlm.nih.gov/pubmed/1966720>. Accessed: Jun. 17, 2015.

LOEFFEN, W.L.A. et al. Seroprevalence and risk factors for the presence of ruminant pestiviruses in the Dutch swine population. Veterinary Microbiology, v.136, n.3-4, p.240-245, 2009. Available from: <http://www.ncbi.nlm.nih.gov/pubmed/19128896>. Accessed: Jun. 17, 2015. doi: 10.1016/j.vetmic.2008.11.011.

NEILL, J.D. et al. Complete genome sequence of pronghorn virus, a Pestivirus. Genome Announcements, v.2, n.3, p.1-2, 2014. Available from: <http://genomea.asm.org/content/2/3/e00575-14. full>. Accessed: Jan. 13, 2016. doi: 10.1128/genomeA.00575-14.

OIE (WORLD ORGANISATION FOR ANIMAL HEALTH). Bovine viral diarrhoea. In: Manual of diagnostics tests and vacines for terrestrial animals. 2015. p.608-710. Available from: <http://www.oie.int/fileadmin/Home/eng/Health standards/ tahm/2.04.08_BVD.pdf>. Accessed: Oct. 26, 2015.

O'SULLIVAN, T. et al. Seroprevalence of bovine vira diarrhea vírus neutralizing antibodies in finisher hogs in Ontario swine herds and targeted diagnostic testing of 2 suspect herds. Canadian Veterinary Journal, v.52, n.12, p.1342-1344, 2011. Available from: <http://www.ncbi.nlm.nih.gov/pmc/articles/ PMC3215470/>. Accessed: Jun. 17, 2015. PMCID: PMC321.

PECORA, A. et al. First finding of genetic and antigenic diversity in 1b-BVDV isolates from Argentina. Research in Veterinary Science, v.96, n.1, p.204-212, 2014. Available from: $<$ http://www. ncbi.nlm.nih.gov/pubmed/24295740>. Accessed: Nov. 09, 2015. doi: 10.1016/j.rvsc.2013.11.004. 
RIDPATH, J.F. et al. Prevalence and antigenic differences observed between Bovine viral diarrhea virus subgenotypes isolated from cattle in Australia and feedlots in the southwestern United States. Journal of Veterinary Diagnostic Investigation, v.22, n.2, p.184-191, 2010. Available from: <http://www.ncbi. nlm.nih.gov/pubmed/20224075>. Accessed: Nov. 09, 2015. doi: $10.1177 / 104063871002200203$.

SIMMONDS, P. et al. Family Flaviviridae. In: KING, A.M.Q. et al. (Eds.). Virus taxonomy: ninth report of the International Committee on Taxonomy of Viruses. San Diego, CA: Elsevier Academic, 2011. p.1003-1020.

SCHROEDER, S. et al. Evaluation of classical swine fever virus antibody detection assays with an emphasis on the differentiation of infected from vaccinated animals. Scientific and Technical Review of the Office International des Epizooties. v.31, n.3, p.997-1010, 2012. Available from: <http:/www.ncbi.nlm.nih.gov/ pubmed/23520753>. Accessed: Nov. 09, 2015. PMID: 23520753.

TAO, J. et al. Bovine viral diarrhea virus (BVDV) infections in pigs. Veterinary Microbiology, v.165, n.3-4, p.185-189, 2013. Available from: <http://www.ncbi.nlm.nih.gov/pubmed/23587625>. Accessed: Jun. 17, 2015. doi: 10.1016/j.vetmic.2013.03.010.

TERPSTRA, C.; WENSVOORT, G. Natural infections of pigs with bovine viral diarrhoea virus associated with signs resembling swine fever. Research in Veterinary Science, v.45, n.2, p.137142, 1988. Available from: <http://www.ncbi.nlm.nih.gov/ pubmed/2848298>. Accessed: Jun. 17, 2015. PMID: 2848298. 